\title{
A declaração de Donald Trump sobre o status de Jerusalém e seu impacto no conflito Israel-Palestina
}

\author{
The statement of Donald Trump on the \\ status of Jerusalem and its impact to the \\ Israel-Palestine conflict
}

DOI: $10.21530 /$ ci.v15n2.2020.941

\author{
Marina D’Lara Siqueira Santos ${ }^{1}$ \\ Matheus de Abreu Costa Souza² \\ Geraldine Rosas Duarte ${ }^{3}$
}

\section{Resumo}

Comumente referenciado como um conflito intratável, a disputa territorial entre Israel e Palestina já dura décadas e o seu fim não parece próximo. Este artigo investiga se há uma relação de interveniência entre o aumento da violência política no conflito Israel-Palestina, a paralisação de tentativas de negociações e o reconhecimento, por parte do presidente dos Estados Unidos da América (EUA), Donald Trump, de Jerusalém como a capital simbólica de Israel. Partindo deste argumento inicial, busca-se identificar de que maneira a interferência estadunidense em um recurso central na disputa pode aumentar o número de eventos violentos entre as partes em conflito e intensificar a natureza intratável da disputa. Levando em consideração (1) o número de eventos violentos; (2) os atores perpetradores da violência;

1 Mestranda e Bacharel (2017) em Relações Internacionais pela PUC Minas. Trabalha atualmente com temas relacionados à Segurança Internacional, com foco no conflito entre Israel e Palestina. ORCID: 0000-0001-70808468; email: marinadlara@gmail.com

2 Doutorando em Relações Internacionais pelo Instituto de Relações Internacionais da PUC-Rio. Mestre (2018) e Bacharel (2016) em Relações Internacionais pela PUC Minas. Trabalha com temáticas relacionadas ao campo de paz e conflitos, com foco na resolução de conflitos internos e peacebuilding pós-conflito. ORCID: 0000-00020734-475X; email: matheusdeacsouza@gmail.com

3 Doutora em Geografia pela PUC Minas (2014), Mestre em Relações Internacionais pela PUC Minas (2009) e Graduada em Relações Internacionais pelo UNIBH (2006). Atualmente é professora do Departamento de Relações Internacionais da PUC Minas, trabalhando com temas relacionados à Segurança Internacional, especialmente no que tange à análise e resolução de conflitos armados. ORCID: 0000-0001-8133-806X; email: geraldine_rosas@ hotmail.com

Artigo submetido em 15/04/2019 e aprovado em 20/12/2019. 
(3) o número de fatalidades reportadas; (4) o local de ocorrência da violência; (5) os atos de violência cotidiana de israelenses contra palestinos e (6) a estagnação de negociações entre as partes em conflito, constatou-se que a interferência estadunidense na disputa entre Israel e Palestina aumentou os enfrentamentos violentos que contribuíram para a intensificação da intratabilidade do conflito.

Palavras-chaves: Conflito Israel-Palestina; Conflitos Intratáveis; Violência Política; EUA; Donald Trump.

\begin{abstract}
Commonly referred to as an intractable conflict, the territorial dispute between Israel and Palestine already lasts decades and its end does not seem near. This article investigates whether there is an intervening relation between the increase of political violence in the Israeli-Palestinian conflict, stalled peace talks attempts, and the recognition, by the President of the United States of America (USA), Donald Trump, of Jerusalem as the symbolic capital of Israel, a city that has been claimed by the parties in conflict. Departing from this initial argument, this article intends to identify how the US interference in a central resource can promote an increase in the number of violent events between the parties in conflict and intensify the intractable nature of the dispute. Taking into account (1) the number of violent events; (2) the perpetrators of violence; (3) the number of reported fatalities; (4) the territory in which violent events took place; (5) the acts of everyday violence of Israeli against Palestinians, and, finally; (6) the stagnation of the negotiations between the parties in conflict, our findings point out that the US interference in the dispute between Israel and Palestine promoted an increase in violent clashes that contributed to the increased intractability of the conflict.
\end{abstract}

Keywords: Israeli-Palestinian Conflict; Intractable Conflicts; Political Violence; USA; Donald Trump.

\title{
Introdução
}

Tendo em vista sua complexidade, o conflito Israel-Palestina é usualmente considerado "intratável”, categoria criada para disputas de longa duração e socialmente enraizadas, nas quais a resolução parece distante por inúmeras razões. Esta intratabilidade está associada a um número recorrente de incidentes violentos e este comportamento violento corrobora com a intratabilidade dos 
conflitos na medida em que prolonga as disputas e promove o recrudescimento dos posicionamentos das partes (Kriesberg 1993, 2003). Este artigo abordará outro fator que pode contribuir para a intratabilidade do conflito Israel-Palestina, a saber, a intervenção estadunidense acerca do status da cidade santa de Jerusalém. Mesmo ciente da relevância de Jerusalém para as partes, o presidente dos Estados Unidos da América (EUA), Donald Trump, reconheceu, em 6 de dezembro de 2017, a cidade como capital de Israel, algo visto pelos palestinos como negação de sua própria identidade. Como Kriesberg (2003) aponta, a presença de questões identitárias nos conflitos intratáveis torna-os mais profundos e difíceis de serem resolvidos.

Dada a relação entre a violência e a intratabilidade, que será abordada com mais profundidade adiante, este artigo busca discutir como a declaração parcial dos EUA perante o conflito israelense-palestino influenciou a dinâmica violenta do conflito e contribuiu para sua intratabilidade. Trabalha-se com a hipótese de que, posteriormente à declaração do presidente estadunidense que ignorou a reivindicação palestina sobre o território de Jerusalém, aumentaram os enfrentamentos violentos entre as partes beligerantes e negociações para a paz foram comprometidas, contribuindo para a intratabilidade do conflito.

Nesse sentido, o objetivo central do presente artigo é investigar se houve aumento da violência no conflito após o pronunciamento do presidente Trump sobre a questão de Jerusalém e, caso se confirme o aumento da violência, como essa intensificação se relaciona com as negociações de paz.. Para realizar esta avaliação, estabelece-se a seguinte relação entre variáveis: (1) a violência, como variável dependente; (2) o posicionamento dos EUA, como variável interveniente, por ser um fato que pode alterar a dinâmica violenta e, por fim; (3) a intratabilidade, como variável independente. Estas variáveis serão avaliadas considerando o período de 07 de dezembro de 2016 a 6 de dezembro de $2018^{4}$ (intervalo que compreende 1 ano antes e um ano após a declaração de Trump). Para cumprir o objetivo do artigo, traçaram-se os seguintes indicadores para avaliar possível intensificação da violência: (1) número de eventos violentos; (2) atores perpetradores da violência; (3) número de fatalidades reportadas; (4) local de ocorrência da violência. Os dados analisados foram coletados no banco de dados "Armed Conflict Location \& Event Data Project” (ACLED). Para além desses dados, relatórios referentes ao período analisado, oriundos da Human Rights Watch e do banco de dados Crisis Watch,

4 Esse recorte metodológico pretende estabelecer uma base de comparação que permita inferir o impacto da declaração de Trump sobre Jerusalém na dinâmica violenta do conflito. 
monitorados pelo International Crisis Group, servirão como referência para observar tipos de violência que excedem os delimitados pela ACLED. Adicionalmente, tais relatórios também servirão como base para análise de possíveis retrocessos nas negociações de paz.

Tendo esse propósito em vista, inicialmente será apresentado um panorama geral do conflito, por meio de adequação entre o objeto de análise e as abordagens teóricas sobre conflitos armados e conflitos intratáveis, visando demonstrar a relevância da cidade de Jerusalém para as partes conflitantes. Posteriormente, será brevemente discutido o papel parcial que os EUA vêm desempenhando no conflito desde seu início, culminando no pronunciamento, em 2017, do seu presidente, Donald Trump, sobre o status de Jerusalém. A partir da exposição teórica e da delimitação do objeto, a última seção, seguida de considerações finais, analisará os dados coletados na base de dados ACLED, nos relatórios da Human Rights Watch e nos relatórios de acompanhamento mensais do Crisis Watch, a fim de refletir sobre a hipótese de aumento da violência e da intratabilidade do conflito.

\section{Compreendendo as causas e a intratabilidade do conflito Israel-Palestina}

Para melhor se compreender as dinâmicas violentas que fazem parte da relação entre Israel e Palestina, é necessário definir o que são conflitos, em primeiro lugar. De acordo com Peter Wallensteen $\left(2007,15\right.$, tradução livre $\left.{ }^{5}\right)$, conflitos podem ser definidos como “(...) uma situação social na qual pelo menos dois atores (partes) se esforçam para obter, em um mesmo momento, um conjunto de recursos escassos". Assim, partindo da definição do autor, todo conflito envolve dois ou mais atores, com interesses que são considerados incompatíveis pelas partes. Esses interesses incompatíveis promovem, então, a competição por um recurso que é escasso (Wallensteen 2007).

A disputa entre Israel e a Palestina pode ser entendida a partir de duas lentes principais que convergem, a simbólica e a territorial. Primeiramente, pontua-se que o simbolismo religioso da região, sobretudo da cidade de Jerusalém, é um grande impasse e se configura como um dos recursos principais em disputa. Conforme Avalos (2005) defende, a religião produz escassez de recursos, que

5 (...) a social situation in which a minimum of two actors (parties) strive to acquire at the same moment in time an available set of scarce resources 
apesar de não poderem ser verificados, uma vez que se baseiam em uma crença no sobrenatural, podem gerar conflito e violência. Os principais recursos religiosos escassos são, de acordo com o autor: o acesso a comunicação divina, acesso aos espaços sagrados, o privilégio de determinados grupos por motivos religiosos e, por fim, a salvação. Apesar do judaísmo e do islamismo produzirem todos os quatro tipos de escassez e, na prática, eles serem articulados entre si, a disputa entre Israel e Palestina diz respeito, principalmente, à escassez de acesso aos espaços sagrados. Segundo Avalos (2005, s/p, tradução livre ${ }^{6}$ ),

[p]odemos definir “espaço sagrado” como um espaço delimitado cujo valor é colocado acima do espaço circundante por razões puramente religiosas. Como nem todos têm acesso ou podem viver em um espaço sagrado, ele se torna um recurso escasso. E como o espaço sagrado é um recurso escasso, ele é um potencial centro de conflito.

A sacralização do espaço pode ocorrer por diversos motivos, desde aqueles inverificáveis, como a presença divina no local, até os mais tangíveis, como a ocorrência de eventos históricos significantes para a religião ou, ainda, por questões econômicas ou políticas. Essa percepção do sagrado pode mudar com o tempo, transitando e combinando diferentes motivos. Segundo o autor, a Palestina não conta com grandes recursos naturais ou um posicionamento geopolítico especialmente estratégico, de modo que a disputa territorial entre palestinos e israelenses não se justifica por um interesse econômico na região, mas por ser um espaço sagrado para ambos (Avalos 2005).

A região palestina concentra os três locais mais relevantes do judaísmo, chamados de anéis concêntricos. O anel primário e mais interno é o Templo de Salomão, construído sobre o Monte Sinai. O próprio Templo contém locais mais sagrados que outros, que expressam uma classificação social e os privilégios de certos grupos. O segundo anel concêntrico se encontra na cidade de Jerusalém, associada à Teologia de Sião. Apesar de não haver certeza sobre a origem dessa teologia, ela afirma que Jerusalém foi escolhida como morada de Javé e protegida por ele, sendo citada como a cidade sagrada em diversos trechos bíblicos. O terceiro anel é a região palestina. Ela é considerada Terra Santa tanto por judeus quanto por cristãos porque, segundo as duas doutrinas religiosas, essa é a terra

6 We may define "sacred space" as a bounded space whose value is placed above that of surrounding spaces for purely religious reasons. Since not everyone has access to, or can live in, a sacred space is a scarce resource. And because sacred space is a scarce resource, it is a potential center of conflict. 
dada por Deus a Abraão. Sendo assim, o valor daquela terra para os judeus não tem viés econômico ou meramente político, mas é essencialmente religioso, simbólico (Avalos 2005).

A percepção desse espaço como sagrado mudou do período bíblico até as reivindicações sionistas atuais. O movimento sionista moderno, que levou a construção do Estado de Israel, era amplamente secular, e outros locais foram propostos como opções para a criação do Estado Judeu. Porém, Avalos (2005) destaca que, mesmo sem vantagens estratégicas e econômicas, a Palestina foi escolhida como o "lar judeu". Isso representou um recrudescimento das reivindicações e interpretações bíblicas, justificando o acesso diferenciado de grupos étnicos ao território. Conforme apontado, as reivindicações religiosas são inverificáveis, como a narrativa de que os judeus são o "povo escolhido", e com isso, produziu um recurso espacial escasso. Nesses espaços, os pontos mais sagrados, como o Templo de Salomão e a cidade de Jerusalém, são os focos centrais de disputa (Avalos 2005).

Por outro lado, Jerusalém também é reivindicada como espaço sagrado para os muçulmanos. Para o Islã, espaços sagrados estão diretamente ligados à separação da população entre grupos privilegiados que podem ter acesso, e aqueles que não são elegíveis. Além disso, ainda estabelecem quais tipos de comportamento são permitidos nesses espaços. Grande parte da sacralidade da região palestina diz respeito a eventos que aconteceram durante o período das Cruzadas, quando foi conquistada por Saladino, mas também às escrituras religiosas que falam sobre eventos inverificáveis, como o encontro de Maomé e Alá. A região mais sagrada é o Domo da Rocha, também localizado em Jerusalém, de modo que a cidade se torna foco de disputa também pelo lado palestino (Avalos 2005).

Com isso, busca-se argumentar que ambas as religiões criam recursos simbólicos escassos na região, principalmente em Jerusalém, de modo que a cidade é ponto crítico para as reivindicações das partes e pode influenciar toda a dinâmica do conflito. Conforme afirma Avalos (2005, s/p, tradução livre ${ }^{7}$ ),

[...] é justo dizer que esse conflito não existiria [...] se os judeus não se considerassem diferentes dos muçulmanos e vice-versa. Em suma, é insustentável ver o conflito entre palestinos e judeus como simplesmente

7 [...] it is fair to say that this conflict would not exist [...] if Jews did not see themselves as different from Muslims, and vice versa. In sum, it is untenable to see the conflict between Palestinians and Jews as simply a secular or political fight for land. The main argument for Palestine as a Jewish homeland is inspired by religious claims from the Bible. Muslims counter with their own scriptural and religious arguments. 
uma luta secular ou política por terra. O principal argumento da Palestina como pátria judaica é inspirado por reivindicações religiosas da Bíblia. Os muçulmanos se opõem a seus próprios argumentos bíblicos e religiosos.

O conflito, assim, é caracterizado por uma luta de reivindicações sobre qual grupo tem mais privilégio sobre esses espaços sagrados compartilhados, de modo que pode-se afirmar que essa reivindicação é compatível com uma contestação da soberania Estatal, uma vez que, em última instância, a soberania garante certo controle sobre esses territórios. Desse modo, é pertinente ressaltar os principais confrontos em relação ao controle do território, principalmente o que diz respeito à cidade de Jerusalém. Ainda durante o Mandato Britânico sobre a região, Jerusalém já era uma cidade de intenso contato entre árabes e judeus (Weingrod 2005). Esse contato aumentou com as constantes ondas de migração judaica para a região, incentivadas principalmente pelo movimento sionista e pela perseguição sofrida pelos judeus na Europa, durante a Segunda Guerra Mundial. Isso gerou um ambiente cada vez mais conflitivo entre as duas populações, de modo que a situação foi levada às Nações Unidas (ONU) em 1947, que decidiu pelo Plano de Partilha. A Resolução 181 previa uma solução de dois Estados, onde seriam criadas duas comunidades políticas independentes, com as cidades de Jerusalém e Belém sob controle internacional (Massoulié 1996).

O Plano de Partilha não chegou a se concretizar, uma vez que, com o fim do Mandato Britânico, Israel declarou independência e tomou o controle de $75 \%$ do território palestino previsto pela ONU, e a parte ocidental da cidade de Jerusalém. Do outro lado, os palestinos não declararam independência e os territórios da Cisjordânia e da Faixa de Gaza foram anexados pela Jordânia, que também controlava a parte oriental de Jerusalém. Em 1967, a configuração territorial se modificou completamente com a Guerra dos Seis Dias, quando Israel anexou a Faixa de Gaza, as Colinas de Golã, o Sinai e Jerusalém Oriental. A população árabe, que residia nas áreas ocupadas, passou a viver sob uma política militarizada e segregativa. Em 1980 e 1999 dois grandes movimentos, de contestação violenta por parte da população palestina, ganharam espaço na região. Chamados de Intifadas, eles defendiam, através do uso da violência, diversas demandas populares, inclusive sobre o status de Jerusalém, que continuava controlada por Israel (Catherwood 2006, Khalidi 2008, Massoulié 1996, Weingrod 2005).

Como é possível perceber, o conflito Israel-Palestina é caracterizado por um litígio territorial com alto contorno simbólico, tendo em vista os espaços sagrados 
disputados. Além disso, o embate entre israelenses e palestinos ainda se caracteriza pela grande atuação de forças não-regulares, como, por exemplo o Fatah e o Hamas, pelo lado palestino, que objetivam a retomada do território ocupado por Israel e a islamização do Estado. Em contrapartida, pelo lado israelense, observa-se a participação intensa de exércitos regulares e forças de segurança do Estado, que recebem treinamento ostensivo para lidar com a dinâmica do conflito. A natureza e os recursos dos atores envolvidos, nesse sentido, são marcados por uma grande assimetria bélica e militar entre as forças israelenses e as palestinas (Aggestam 1999).

A longa duração do conflito, a demanda pelo território e o alto componente identitário em torno da disputa são aspectos que contribuem para que a possibilidade de envolvimento das partes em negociações para a paz seja vista com desconfiança. Assim, os interesses de soma-zero que envolvem o conflito, aliados ao alto nível de antagonismo, são aspectos que contribuem para o seu prolongamento, fazendo com que ele adquirisse, ao longo dos anos, característica de intratabilidade ${ }^{8}$ (Kriesberg 2003, 1993, Oren et al., 2004).

Os conflitos intratáveis “(...) são formalmente definidos como totais, violentos, de natureza de soma-zero e percebidos como irreconciliáveis; durando ao menos uma geração e envolvendo todos os membros da sociedade”. (Oren et al., 2004, 151, tradução livre ${ }^{9}$ ). Nessa modalidade de conflitos armados, é possível identificar algumas singularidades que caracterizam a diferença dos conflitos intratáveis para outras formas de mobilização armada. A primeira delas é que esses possuem longa duração, haja vista que as partes têm posicionamento rígido em relação a suas demandas. A segunda característica está aliada à anterior, pois, devido a este prolongamento, os conflitos intratáveis geralmente podem apresentar ausência total de negociações ou grande número de tentativas fracassadas de estabelecer a paz. Com isso, o cenário é marcado pela desconfiança entre as partes, pois a ausência de negociações ou violações de acordos anteriores fazem com elas enxerguem com descrença a possibilidade de paz no futuro.

A terceira característica dos conflitos tange a questão da violência. Os conflitos intratáveis podem apresentar dinâmicas que variam entre o emprego constante da

8 É necessário enfatizar que classificar o conflito como “intratável” não significa que ele não seja passível de ser resolvido, pois a ideia de intratabilidade presente na literatura sobre conflitos armados remete a uma situação de difícil resolução, tendo em vista uma série de características (Oren et al. 2004, Crocker, Hampson e Aall 2004).

9 (...) are formally defined as being total, violent, of zero sum nature, and perceived as irreconcilable; as lasting at least a generation; as involving all society members. 
violência pelos atores envolvidos ou por atos violentos esporádicos, que levam os conflitos a uma situação de congelamento, em que as partes não se enfrentam com muita constância, mas também não estão dispostas a negociar. No caso de conflitos violentos, o recurso de uso da força, quando utilizada em demasia, aumenta a intratabilidade de um conflito. Nesse sentido, quando a violência é utilizada como forma de repressão, é possível identificar que as partes adotam posturas ainda mais antagônicas. A última característica dos conflitos intratáveis é que apresentam altos níveis de antagonismo, o que leva as partes a terem uma autoimagem de que elas são as vítimas, excluindo suas responsabilidades como perpetradoras da violência. Além disso, esse antagonismo pode estar relacionado a aspectos identitários, como religião, cultura, etnia, dentre outros (Crocker, Hampson e Aall 2004).

Todas as características dos conflitos intratáveis são identificáveis no conflito Israel-Palestina. Primeiramente, observa-se que, em 2018, o conflito completou setenta anos de duração, tendo início em 1948 com a declaração e independência de Israel. Analisando a segunda e terceira características da intratabilidade, percebe-se que, de modo geral, elas caminham juntas no conflito: em um primeiro momento houve um congelamento das negociações, e quando elas começaram de fato, a partir de 1993, com o reconhecimento mútuo das partes ${ }^{10}$, grande parte das futuras negociações foram antecedidas ou sucedidas por episódios de violência11 (Massoulié 1996).

A última característica dos conflitos intratáveis, relacionada à construção dos antagonismos e à vitimização das partes, também está presente no conflito Israel-Palestina. Além dos fatores de antagonismos já discutidos, a vitimização é característica fundamental da construção mútua de mitos fundacionais. Para os israelenses, a vitória em 1948 contra os árabes é considerada um milagre, criando uma analogia da Guerra de 1948 com o confronto bíblico de David e o gigante Golias, ignorando a superioridade bélica que os israelenses tinham em relação aos árabes e focando na superioridade quantitativa do inimigo. Para eles, a vitória de

10 Como Peter Wallensteen (2007) esclarece, o processo de resolução de um conflito consiste em uma situação na qual as partes entram em acordo para resolver suas incompatibilidades. Tal acordo indica que cada oponente aceita que o outro continue existindo enquanto uma "parte", no sentido de que aceitam que o outro lado seja, no futuro, um ator com o qual tenham que negociar. Isso significa que nenhum dos lados vence totalmente, ganhando tudo o que é possível, mas significa, também, que nenhuma das partes perde tudo, de modo que ninguém se torna o único perdedor.

11 Exemplos: Acordos de Oslo (1993), que sucedeu a Primeira Intifada (1988-1993); Acordos de Camp David (2000), que antecederam a Segunda Intifada (2000-2005); e The Road Map for Peace (2005), que antecedeu diversas operações militares de Israel na Faixa de Gaza (Harms e Ferry 2017). 
Israel reforça o direito sagrado dos judeus à Terra Prometida. Entre os palestinos, o mito é construído na representação da Nakba e retratam os israelenses como um inimigo quase impossível de se derrotar. Como os israelenses, os palestinos e também os demais países árabes, esquecem de observar as próprias falhas no decorrer do conflito que, por fim, ocasionaram a derrota da aliança árabe (Khaladi 2008, Morris 2008).

No caso do conflito entre Israel e Palestina, a intratabilidade está associada, dentre outros fatores, à presença de violência, na medida em que este fenômeno deteriora as relações entre as partes. A dinâmica violenta apresenta um caráter altamente politizado nos conflitos armados, e, nesse sentido, trata-se de uma modalidade específica de violência, a violência política, que ocorre quando “(...) o uso da força por um grupo possui propósito ou motivação política” (ACLED, 2018, 1, tradução livre ${ }^{12}$ ). A violência política pode contribuir para a intratabilidade na medida em que prolonga os conflitos, aumenta o antagonismo entre as partes, gerando descrença acerca da possibilidade de paz no futuro (Oren et al., 2004, Crocker, Hampson e Aall 2004). Contudo, a visão de violência política mobilizada pela ACLED, base de dados que será utilizada adiante, não considera atos de violência política "invisíveis". Portanto, será analisada não somente a violência política direta, que é aquela corporal, que busca matar, ferir, aprisionar o inimigo por motivações políticas, mas, também, a violência silenciosa, que permeia as estruturas das relações sociais e é comumente naturalizada pela sociedade. Essa violência estrutural pode ser percebida nas desigualdades sociais, nos privilégios e até em aspectos psicológicos, como a constante humilhação e assédio sobre um grupo (Galtung 1969).

Um último aspecto relevante em relação aos conflitos intratáveis está relacionado a possível atuação de atores terceiros para tentar mitigar ou reduzir a condição de intratabilidade de disputas armadas desta natureza. De acordo com Crocker, Hampson e Aall(2004), o não envolvimento de atores externos ao conflito é uma alternativa compreensível e, em muitos casos, recomendada. Isto porque, em conflitos intratáveis, para além dos interesses irreconciliáveis, as partes envolvidas possuem identidades muitas vezes vistas como excludentes, aspecto que inibe a vontade das lideranças de se engajar em conversações para a paz. Assim, se os envolvidos não conseguem, voluntariamente, estabelecer um cenário de negociação, não há razões para que atores externos tentem, de alguma

12 (...) use of force by a group with a political purpose or motivation. 
maneira, mediar o conflito em questão (Crocker, Hampson e Aall 2004). Nesse sentido, Crocker, Hampson e Aall (2004) sugerem que atores terceiros atuem na lógica do conflito somente quando seus interesses diretos ou sua soberania estejam sendo ameaçados pela disputa violenta.

A despeito da sugestão dada pelos autores, no caso do conflito Israel-Palestina é possível identificar alto nível de atuação de terceiras partes, sobretudo dos Estados Unidos, que, desde a deflagração da violência no conflito, concedem apoio incondicional à causa sionista defendida pelo governo israelense. Assim, tendo em vista o alto nível de interferência estadunidense na dinâmica do conflito, esse aspecto será discutido na seção seguinte.

\section{A parcialidade dos EUA no conflito Israel-Palestina}

Desde antes da independência de Israel, os EUA já apoiavam o movimento sionista e demostravam seu suporte incondicional ao país, resultado principalmente da pressão exercida pelo lobby judaico nos EUA. Esse lobby é entendido como "a frouxa coalizão de indivíduos e organizações que trabalham ativamente para empurrar a política externa dos Estados Unidos numa direção pró-Israel” (Mearsheimer e Walt 2006, 50), sejam eles judeus, em sua maioria, ou cristãos evangélicos. As ações incluem votos e colaboração com a eleição de congressistas favoráveis à causa israelense, além do controle do debate interno sobre o assunto, seja pela mídia ou por think-tanks, evitando assim, que a opinião púbica se vire contra Israel. Além disso, os funcionários dedicados à política externa estadunidense em relação ao Oriente Médio possuíam relações estreitas com o lobby judaico no país. Dessa forma, é possível inferir que esse lobby influenciou na atuação estadunidense no conflito Israel-Palestina ao longo das décadas (Mearsheimer e Walt 2006).

A despeito do apoio incondicional a Israel, os EUA se posicionaram contrariamente aos assentamentos israelenses no território da Palestina desde a Guerra dos Seis Dias (1967). Esse posicionamento mudou em 2004, com o governo de George W. Bush, quando o presidente declarou que era irreal negociar o retorno das fronteiras israelenses de 1949, afirmando que os assentamentos já eram um fato e que o processo de paz só continuaria com a aceitação dessa realidade (Gelvin 2011). O presidente reiterou que, para que o processo de paz realmente acontecesse, a Palestina deveria buscar nova forma de liderança, uma vez que 
tanto os EUA quanto a União Europeia e a Organização das Nações Unidas (ONU) se negavam a dialogar com o Hamas, que controlava a Faixa de Gaza e era considerado internacionalmente um grupo terrorista (Harms e Ferry 2017).

O ano de 2009 se inicia com mudanças nas lideranças de Israel e dos Estados Unidos. Benjamin Netanyahu, primeiro ministro israelense, deu continuidade à política de assentamentos de Israel, afastando-se um pouco do governo estadunidense, que, com Barack Obama, voltava a condenar os assentamentos e tentava novos caminhos para as negociações de paz. Apesar disso, pouco se fez no sentido de dissuadir Israel a continuar a ocupação. Porém, pode-se dizer que o governo Obama terminou com uma ação simbólica significativa de redenção. Após um governo que retoricamente se colocava contrário às ocupações, mas, na prática, deu continuidade à política externa do governo Bush, os EUA se abstiveram, pela primeira na história, em uma resolução do Conselho de Segurança que condenava as ações de Israel. Segundo a Resolução 2334, de 2016, os assentamentos israelenses na Cisjordânia não possuem validade legal e deveriam cessar imediatamente (Harms e Ferry 2017). Apesar do peso simbólico da abstenção estadunidense, o atual presidente dos Estados Unidos, Donald Trump, que já havia vencido as eleições quando a Resolução foi aprovada, prometeu, enquanto aguardava a posse: “[q] uanto à ONU, as coisas serão diferentes depois de 20 de janeiro” (Trump 2016 apud Harms e Ferry 2017, 208, tradução livre13).

A parcialidade estadunidense no que tange ao conflito entre Israel e Palestina foi reforçada em 6 de dezembro de 2017, quando Trump, reconheceu a cidade de Jerusalém como a capital do Estado de Israel e anunciou a mudança da embaixada dos EUA de Tel Aviv para a cidade (White House 2017). É necessário frisar que, no Plano de Partilha de 1947, proposto no âmbito da ONU, a criação de Israel e Palestina como Estados independentes excluía o controle das partes sobre a cidade de Jerusalém, sendo esta reconhecida como uma zona de administração internacional (ONU 1947). Desde então, em respeito aos termos acordados em 1947, os Estados têm se esquivado de discutir o status atual de Jerusalém, preferindo localizar suas respectivas embaixadas na cidade de Tel Aviv, internacionalmente considerada capital israelense (Quigley 1994).

A medida adotada por Trump foi prometida durante sua campanha eleitoral, período em que o presidente enfatizou o direito dos judeus sobre a escolha de sua capital. Uma das promessas feitas durante a campanha foi a consecução da

13 As to the UN, things will be different after Jan 20 . 
lei pública aprovada no congresso estadunidense, em 8 de novembro de 1995, denominada "Jerusalem Embassy Act", que previa a mudança da embaixada de Tel Aviv para Jerusalém (EUA 1995, Cherkaoui 2017). O documento, além de reconhecer Jerusalém como a capital de Israel, também declara o direito do Estado israelense sobre a região, com base em antecedentes históricos e pelo fato de que a cidade passou a ser administrada pelos israelenses desde 1967 (EUA 1995).

Embora a medida tenha sido aprovada em 1995, os presidentes estadunidenses subsequentes não implementaram a mudança da embaixada para Jerusalém, prevista para 1999, temendo uma escalada do conflito. Por sua vez, Trump retomou a discussão sobre o status de Jerusalém, demonstrando seu posicionamento favorável ao direito de Israel sobre a cidade, ao afirmar que os EUA “(...) finalmente reconhecem o óbvio: que Jerusalém é a capital de Israel. Isso não é nada mais ou menos do que reconhecimento da realidade" (White House 2017, [s.p], tradução livre ${ }^{14}$ ). O discurso do presidente ressaltou que outros Estados (e também os governos anteriores ao seu) se esquivaram da discussão sobre o status de Jerusalém e que isso não promoveu a resolução efetiva do conflito. Nesse sentido, Trump defendeu que a transferência da embaixada dos EUA para a cidade seria apenas o reconhecimento de algo óbvio e que não afetaria o processo de paz (White House 2017).

Ademais, o pronunciamento também enfatiza, em diversas passagens, o anseio estadunidense de se engajar na resolução do conflito (White House 2017). Entretanto, na prática, a resolução de um conflito depende de um cenário em que as partes percebem que o processo de paz é mais vantajoso do que permanecer no conflito armado (Wallensteen 2007). Assim, em consequência dessa necessidade de se encontrar um denominador comum, não é possível pensar em um processo de resolução no qual os recursos em disputa, no caso, o território e a cidade de Jerusalém, não sejam devidamente negociados e divididos. Logo, o discurso estadunidense de promoção da paz contraria os princípios da resolução de conflitos ao declarar o direito de Israel em controlar a cidade de Jerusalém. Como argumentado na seção anterior, a cidade também possui relevância material e simbólica para os palestinos e está no eixo central da reivindicação das partes. Assim, a "decisão de Trump representa uma proposição de soma zero em favor dos israelenses” (Cherkaoui 2017, 11, tradução livre'5).

14 (...) we finally acknowledge the obvious: that Jerusalem is Israel's capital. This is nothing more, or less, than a recognition of reality.

15 Trump's decision represents a zero-sum proposition in favor of the Israelis. 


\section{Análise da dinâmica violenta no conflito Israel-Palestina}

A partir da caracterização da violência política, feita na primeira seção, a base de dados "Armed Conflict Location \& Event Data Project" (ACLED) coleta informações de eventos violentos que se enquadram nesse conceito. Para este artigo, serão utilizados os dados da ACLED acerca dos eventos de violência política envolvendo a díade Israel-Palestina, entre 7 de dezembro de 2016 a 6 de dezembro de 2018. Os eventos são classificados pela base de dados em quatro categorias: (1) batalhas - confrontos violentos diretos entre dois grupos distintos, estatais ou não-estatais; (2) violência remota - eventos que utilizam a violência sem que o perpetrador esteja presente; (3) rebeliões - demonstrações violentas por parte de uma sociedade; e (4) violência contra civis - configurada quando um grupo armado, estatal ou não, faz uso da força contra civis desarmados (ACLED 2018). Tais definições, bem como seus respectivos indicadores, estão dispostos no Quadro 1, abaixo.

Quadro 1. Violência Política: categorias, definiçõos e indicadores

\begin{tabular}{|c|c|c|}
\hline Categoria & Definição & Indicadores \\
\hline Batalhas & $\begin{array}{l}\text { “(...) confrontos violentos entre pelo menos } \\
\text { dois grupos armados. Os tipos de batalha } \\
\text { são diferenciados se o controle de um local } \\
\text { é inalterado como consequência do evento; } \\
\text { se um grupo não estatal assumiu o controle } \\
\text { de um local ou se um governo retomou } \\
\text { o controle desse local” (ACLED 2018, 1, } \\
\text { tradução livre) }{ }^{16} \text {. }\end{array}$ & $\begin{array}{l}\text { 1. Choque armado; } \\
\text { 2. Governo recupera território; } \\
\text { 3. Ator não-estatal alcança território }\end{array}$ \\
\hline $\begin{array}{l}\text { Violência } \\
\text { Remota }\end{array}$ & $\begin{array}{l}\text { “(...) eventos onde uma explosão, bomba } \\
\text { ou outro dispositivo explosivo foi usado } \\
\text { para envolver-se em conflitos. Eles incluem } \\
\text { eventos violentos unilaterais, nos quais a } \\
\text { ferramenta para se envolver em conflitos } \\
\text { cria assimetria, eliminando a capacidade } \\
\text { do alvo de se envolver ou defender a si } \\
\text { próprio e sua localização” (ACLED 2018, } 2 \text {, } \\
\text { tradução livre) }{ }^{17} \text {. }\end{array}$ & $\begin{array}{l}\text { 1. Armas químicas; } \\
\text { 2. Ataques aéreos/drones; } \\
\text { 3. Granadas; } \\
\text { 4. Ataques suicidas; } \\
\text { 5. Explosivos remotos; } \\
\text { 6. Minas terrestres; } \\
\text { 7. Bombardeios; } \\
\text { 8. Artilharia; } \\
\text { 9. Ataques com mísseis; } \\
\text { 10. Artefatos explosivos improvisados }\end{array}$ \\
\hline
\end{tabular}
continua...

16 (...) are violent clashes between at least two armed groups. Battle types are distinguished by whether control of a location is unchanged as a consequence of the event; whether a non-state group has assumed control of a location, or whether a government has resumed control of that location.

17 (...) events where an explosion, bomb or other explosive device was used to engage in conflict. They include one-sided violent events in which the tool for engaging in conflict creates asymmetry by taking away the ability of the target to engage or defend themselves and their location. 
continuação

\begin{tabular}{|c|c|c|}
\hline Categoria & Definiçãa & Indicadores \\
\hline Rebeliões & $\begin{array}{l}\text { “(...) demonstração violenta, geralmente } \\
\text { envolvendo ação espontânea por membros } \\
\text { da sociedade não-organizados e sem filia- } \\
\text { ção" (ACLED 2018, 3, tradução livre) }{ }^{18} \text {. }\end{array}$ & $\begin{array}{l}\text { 1. Demonstrações violentas; } \\
\text { 2. Tumultos violentos. }\end{array}$ \\
\hline $\begin{array}{l}\text { Violência } \\
\text { Contra } \\
\text { Civis }\end{array}$ & $\begin{array}{l}\text { “(...) envolve ataques violentos contra civis } \\
\text { desarmados” (ACLED 2018, 3, tradução } \\
\text { livre) }{ }^{19} \text {. }\end{array}$ & $\begin{array}{l}\text { 1. Desaparecimento forçado; } \\
\text { 2. Abdução; } \\
\text { 3. Violência sexual; } \\
\text { 4. Ataques. }\end{array}$ \\
\hline
\end{tabular}

Fonte: Elaboração própria, com base em ACLED (2018).

Tendo como referência as categorias citadas acima, foram identificados, ao longo do período analisado, a ocorrência de 6.154 eventos enquadrados como atos de violência política envolvendo Israel e Palestina. Entre os dados coletados, a violência política propagada por meio de rebeliões foi a grande maioria, totalizando 4.040 episódios, correspondendo a aproximadamente 65,65\% do total de eventos reportados. Em números bastante inferiores, a violência remota aparece como o segundo tipo de violência política mais recorrente no período, com um total de 1.000 atos violentos (aproximadamente 16,25\% do total de eventos). Por sua vez, a ocorrência de atos de violência contra civis representou 13,23\% (814 eventos) da amostra. Por fim, a forma de violência política menos recorrente, totalizando 300 eventos no período $(4,87 \%)$, foram as batalhas violentas diretas entre Israel e Palestina. O Gráfico 1, abaixo, evidencia a distribuição dos eventos violentos por tipo e por mês, considerando o período analisado.

\section{Gráfico 1. Tipos de violência política envolvendo Israel e Palestina}

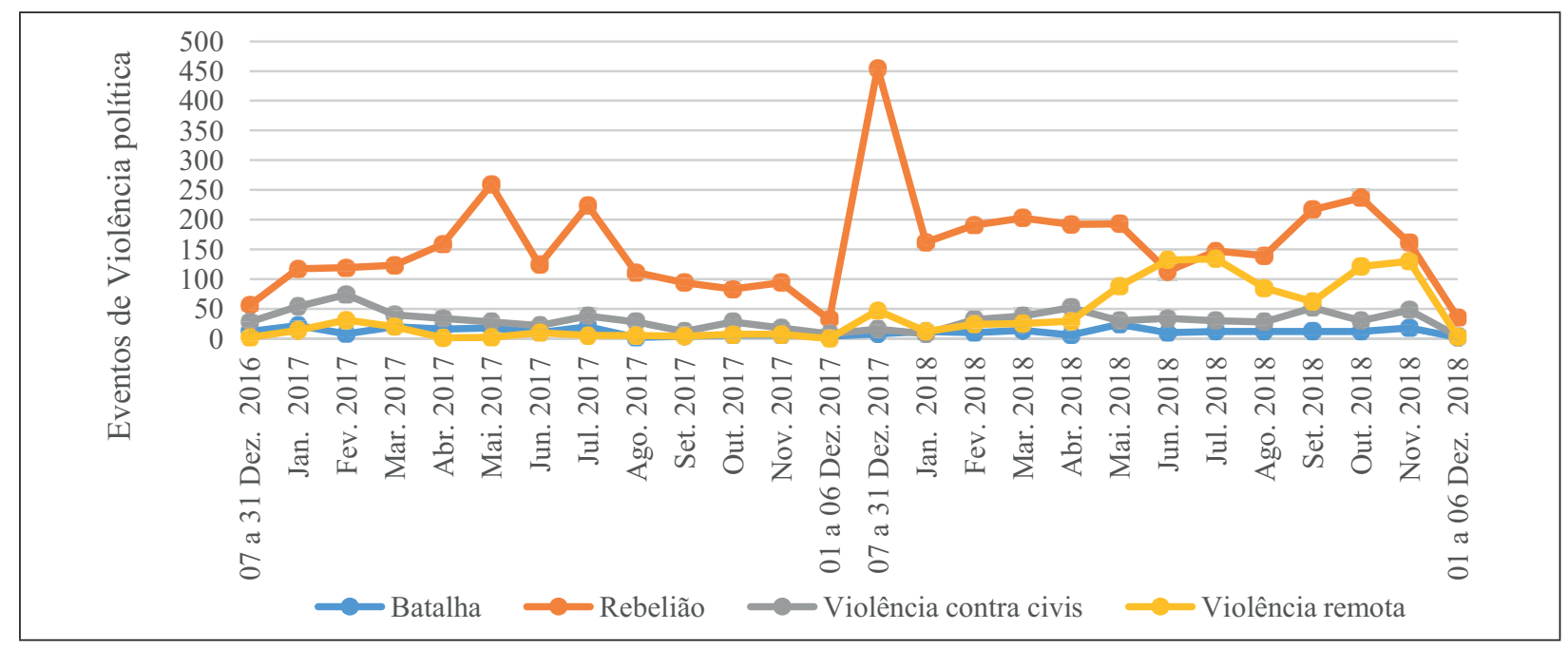

Fonte: Elaborado pelos autores, com base em ACLED (2019).

18 (...) a violent demonstration, often involving a spontaneous action by unorganized, unaffiliated members of society. 19 (...) involves violent attacks on unarmed civilians. 
Com base nos dados dispostos no gráfico anterior, é possível realizar algumas inferências. No período de 07 de dezembro de 2016 até 06 de dezembro de 2017, um total de 2.263 eventos foram registrados. Por sua vez, nos doze meses posteriores ao anúncio da mudança da embaixada estadunidense para Jerusalém (de 07 de dezembro de 2017 até 06 de dezembro de 2018), houve um aumento geral do total de eventos violentos envolvendo Israel e a Palestina, totalizando 3.891 eventos, representando um acréscimo significativo de aproximadamente $72 \%$ da quantidade total de eventos, em comparação ao período anterior. Outra constatação a ser feita é que dezembro de 2017, após o pronunciamento de Trump, é o período com maior número de atos violentos entre as partes, mostrando uma relação de interveniência direta entre o anúncio estadunidense sobre o status de Jerusalém e o aumento da violência. Por fim, embora no ano de 2018 o total de eventos tenha diminuído, estes ainda apresentam altos níveis em comparação aos doze meses anteriores.

Diversos atores estiveram envolvidos na propagação da violência política no período selecionado. Em um primeiro momento, foram categorizados os atores como defensores da causa de Israel ou da Palestina, sendo estes estatais ou não. Além disso, também notou-se o envolvimento mínimo de alguns atores internacionais. Dentre os 6154 eventos de violência política analisados, 3081 foram propagados por atores palestinos $(50,06 \%), 3033$ por atores israelenses $(49,29 \%)$ e 40 por atores internacionais $(0,65 \%)$.

Gráfico 2. Distribuição mensal, e por ator, dos eventos de violência política

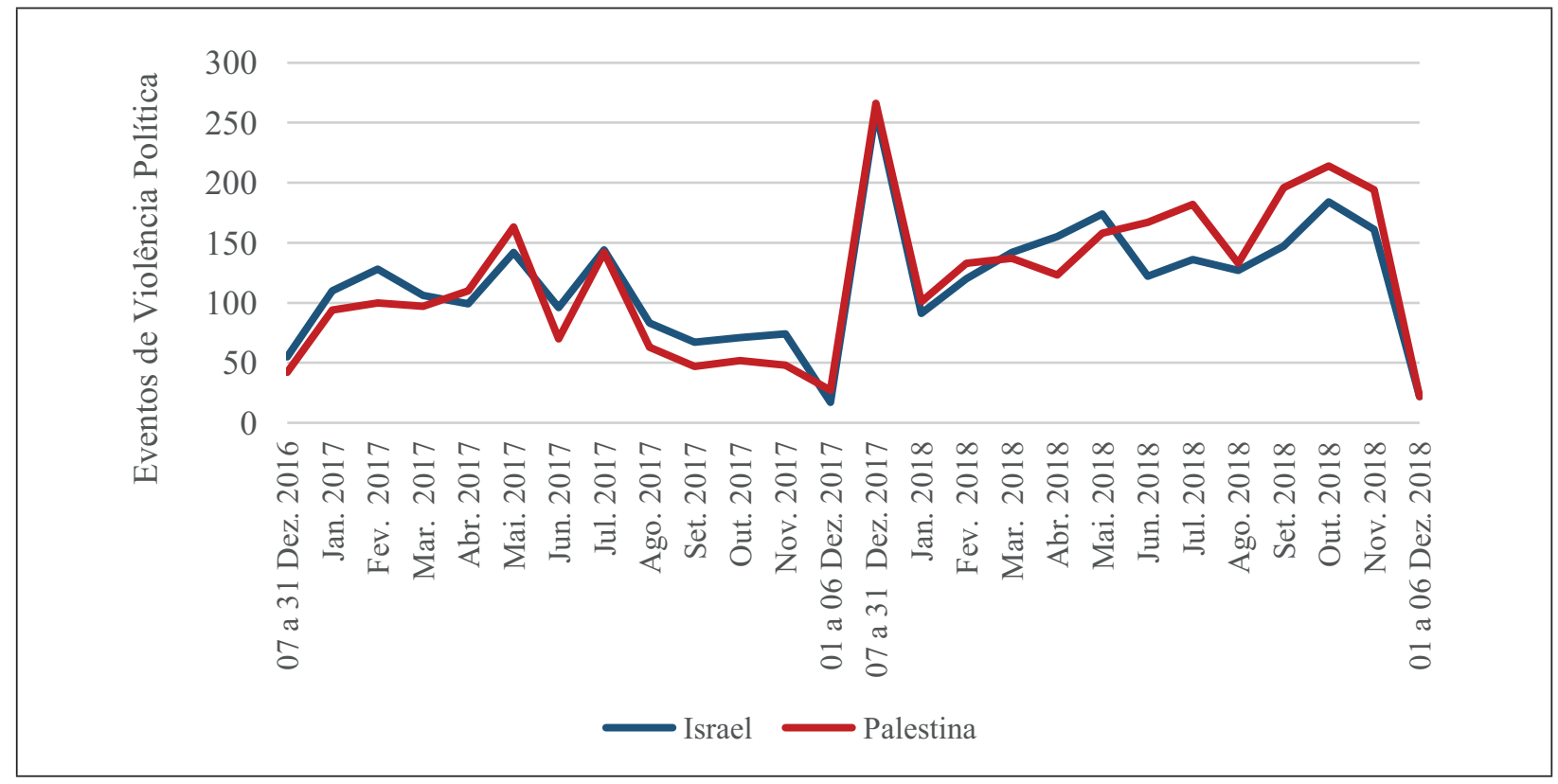

Fonte: Elaborado pelos autores, com base em ACLED (2019). 
Em relação ao período analisado, percebeu-se que $34,24 \%$ dos eventos de violência realizados em defesa da causa palestina ocorreram no período anterior ao discurso de Trump, enquanto $65,76 \%$ ocorreram após o pronunciamento, apontando que a medida adotada pelos EUA foi, de fato, vista como parcial e influenciou a escolha pelo comportamento violento. A intensificação da atuação da parte palestina também provocou alteração no comportamento israelense, na medida em que houve um aumento de 54,4\% do envolvimento israelense em eventos de violência política no período pós declaração de Trump. Nota-se, então, que há uma correlação entre o reconhecimento estadunidense de Jerusalém como capital de Israel e o aumento da incidência de atos de violência política entre as partes envolvidas no conflito.

Após essa análise inicial, estratificaram-se as categorias Israel e Palestina, com o propósito de analisar quem são os atores que mais perpetuam violência política dentro de cada categoria ${ }^{20}$. Israelenses e Palestinos foram separados entre "atores estatais", "civis" e "grupos armados". Ao estratificar os dados referentes aos perpetradores da violência política, percebe-se uma assimetria. Dentre os 3033 eventos de violência política registrados no período pela categoria "Israel”, 77,3\% foram realizados pelo Estado de Israel, e em sequência, mas em proporção bem menor estão os Civis Israelenses (22\%) e Grupos Armados Israelenses ${ }^{21}$ (0,7\%). Em contraposição, os maiores perpetradores de violência política na categoria "Palestina" são os Civis Palestinos, responsáveis por 2308 eventos de violência política, ou seja, aproximadamente $75 \%$, seguidos de Grupos Armados Palestinos 22 $(24,3 \%)$ e por último, as forças regulares palestinas, que realizaram apenas 22 eventos de violência política no período analisado $(0,7 \%)$.

20 Não foi estratificada a categoria Internacional, uma vez que os dados envolvidos com esse ator representam menos de $1 \%$ da amostra.

21 Todos os eventos de violência política contabilizados nessa categoria foram realizados por grupos armados israelenses não identificados.

22 Nesta categoria estão contabilizados os eventos realizados pelos seguintes grupos: Ahfad al SahabaAl Ghara Communal Militia, Al Nasser Salah al Deen Brigades, Fatah Movement, Hamas Movement, Islamic State, Islamist Militia, Popular Front for the Liberation of Palestine, Palestinian Islamic Jihad, Sons of Zouari e outros grupos armados não identificados. 
Gráfico 3. Estratificação dos eventos de violência política por ator

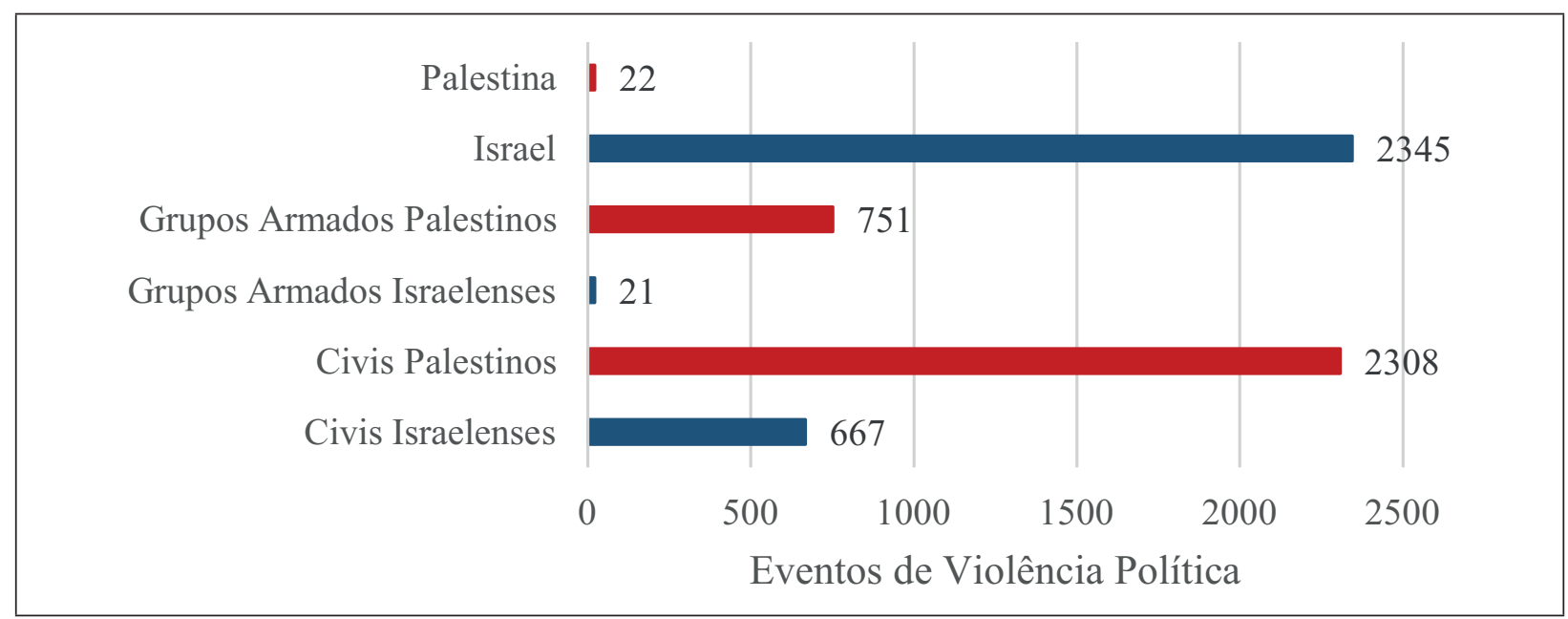

Fonte: Elaborado pelos autores, com base em ACLED (2019).

Percebe-se a proeminência de ação de forças regulares pelo lado israelense - apenas $23 \%$ da violência política de Israel foi efetuada por grupos armados e civis - e uma extensão de grupos de forças não-regulares pelo lado palestino 99\% da violência política é promovida por grupos armados e civis. Percebe-se, ainda, que essa característica se traduz no fato de que a maioria dos eventos de violência política ocorrem em rebeliões, como apresentado acima. Na categoria de violência política, aproximadamente 46,7\% dos eventos foram perpetrados por Civis Palestinos e $37 \%$ pelo Estado de Israel. Além disso, a situação apresentada demonstra grande assimetria no conflito, favorável ao lado israelense, uma vez que forças regulares normalmente possuem maior poder bélico que grupos armados e civis, o que ainda favorece a vitimização do enorme número de civis palestinos envolvidos no conflito. É interessante notar que, após o pronunciamento de Trump, aumentou a participação dos palestinos em eventos de violência política, inclusive por parte dos Grupos Armados Palestinos, que atuaram $325 \%$ mais do que em relação ao período anterior, e de civis, que subiu $57 \%$ sua atuação. Já pelo lado israelense, apenas a atuação do Estado de Israel aumentou 82\%, enquanto a atuação de civis e grupos armados diminuiu após o pronunciamento $8 \%$ e $25 \%$ respectivamente.

A localização dos eventos envolvendo violência política é outro indicador interessante, que permite avaliar a maior vitimização. Analisando os dados, percebe-se grande assimetria, pois 5162 eventos, 83,9\% do total, ocorreram em territórios palestinos da Cisjordânia e na Faixa de Gaza, enquanto apenas 992 eventos, 16,1\% do total, deram-se em território israelense, conforme apresentado no Gráfico 4, abaixo. 


\section{Gráfico 4. Distribuição espacial dos eventos de violência política}

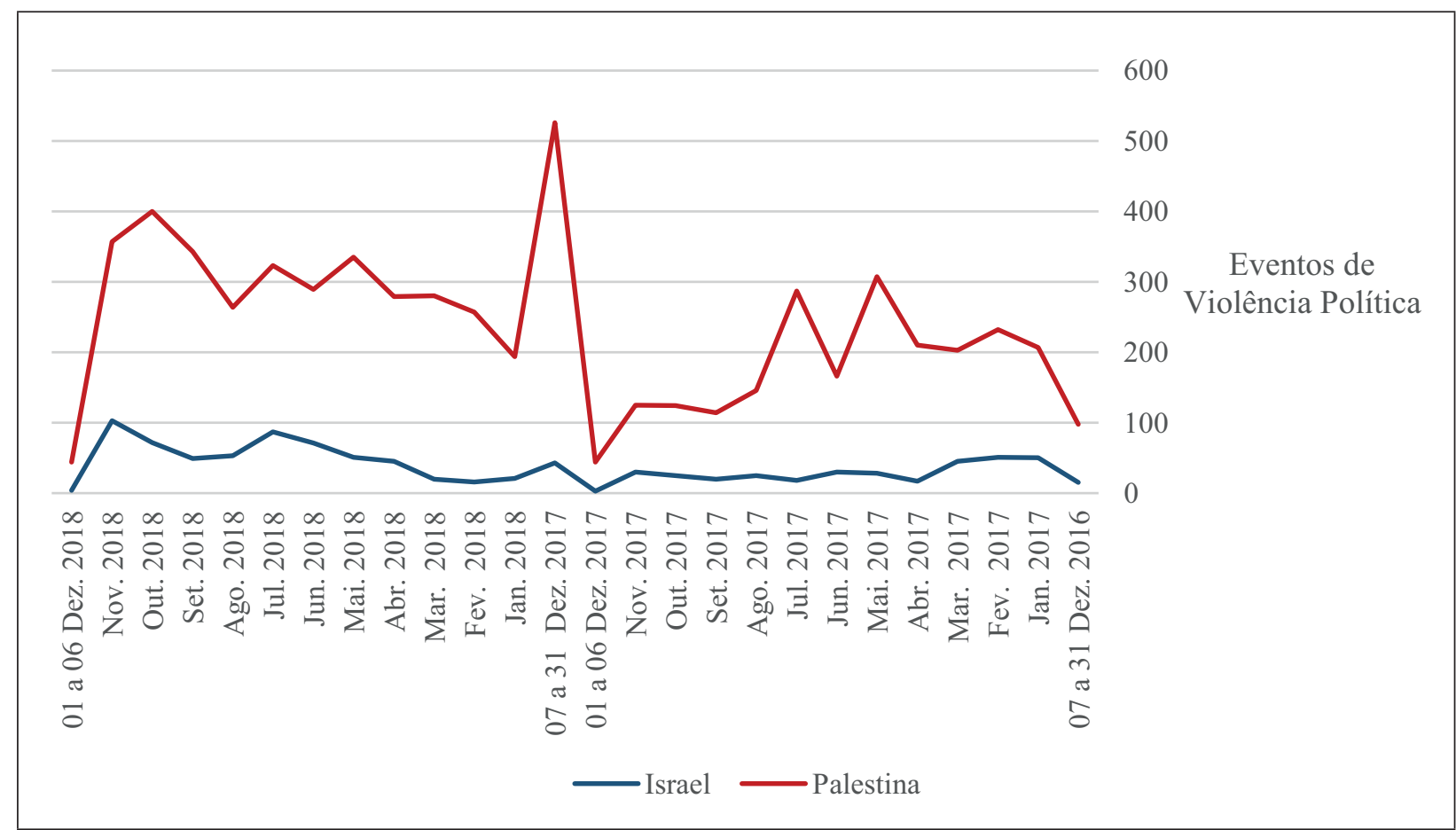

Fonte: Elaborado pelos autores, com base em ACLED (2019).

O percentual da localização da violência pouco variou antes e depois do discurso de Trump, logo, não há grande relação de interveniência. Entretanto, é válido ressaltar que o aumento quantitativo do total de eventos envolvendo a violência política em território palestino (1906 atos contabilizados até 6 de dezembro, e 3256 atos após essa data) pode contribuir para a intratabilidade, na medida em que os ocorridos passaram a ser ainda mais frequentes na vida da população. Assim, a convivência com atos de violência pode contribuir para a intratabilidade do conflito Israel-Palestina na medida em que aumenta o antagonismo entre as partes, contribuindo para que os palestinos reforcem sua autoimagem de vítimas, já que a maior parte dos atentados ocorreu em seu território.

O último indicador a ser analisado é o da quantidade de vítimas fatais reportada. Durante o período analisado, foram reportadas 920 mortes, sendo que 455 ocorreram em eventos de violência guiados por atores associados ao lado palestino, ao passo que se notificou 460 vítimas em eventos propagados por atores associados ao lado israelense. Por fim, 5 vítimas fatais reportadas estão associadas a eventos propagados por atores internacionais. Porém, é importante salientar que a ACLED não especifica a origem das vítimas (palestinos ou israelenses). Sendo assim, os dados dispostos no Gráfico 5, abaixo, consideram apenas o local onde as fatalidades ocorreram. 
Gráfico 5. Fatalidades por data e local

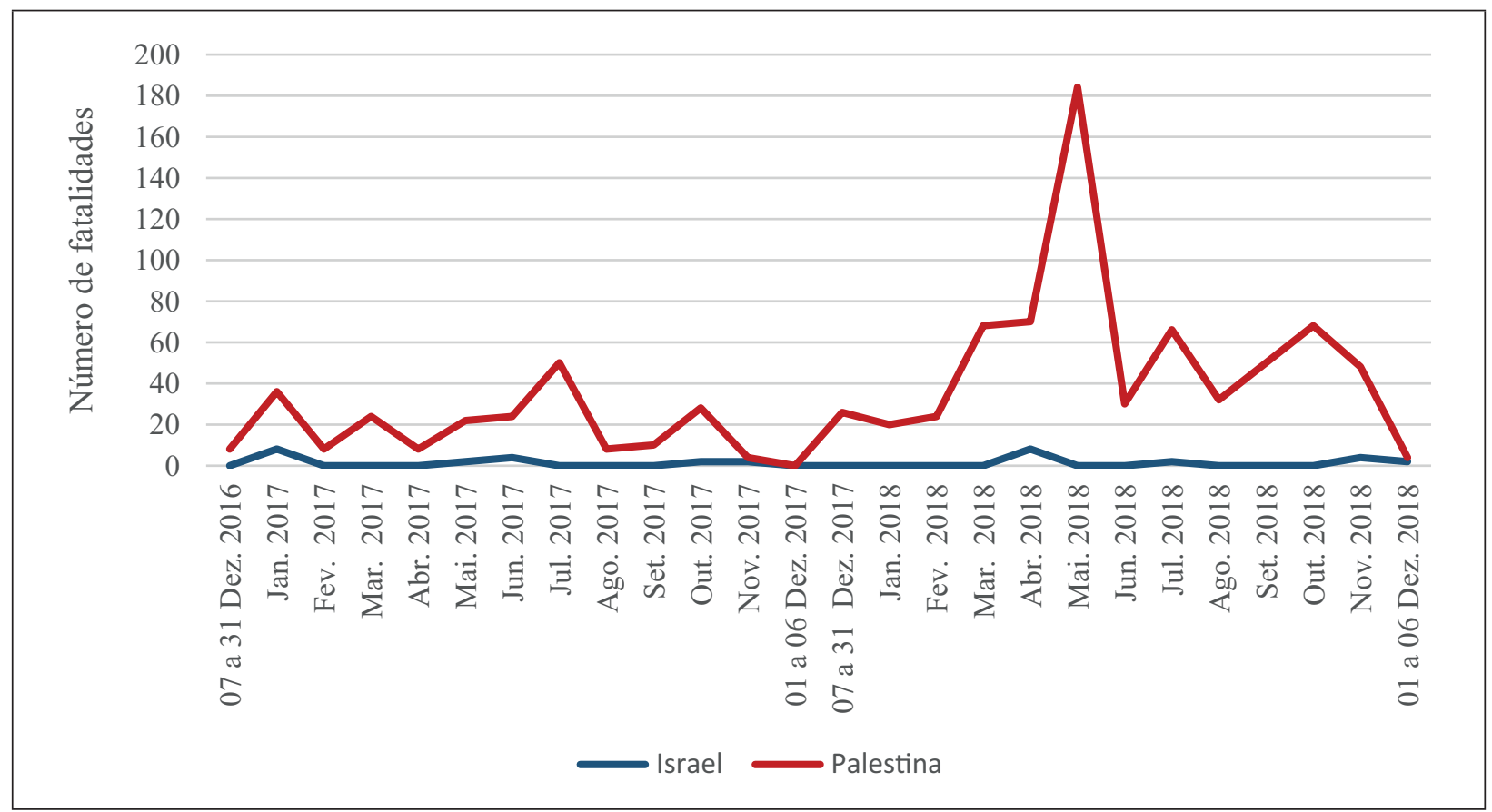

Fonte: Elaborado pelos autores, com base em ACLED (2019).

Das 920 fatalidades, 886 ocorreram em território palestino, ou seja, 96,3\%. Além disso, 51,3\% das mortes ocorreram em rebeliões, seguidas de 23,3\% em batalhas, $15 \%$ em violência remota e $10,4 \%$ por violência contra civis. Embora não seja possível precisar, o dado indica que há maior probabilidade de que as vítimas sejam palestinas, tendo em vista a localização e o fato de os confrontos serem majoritariamente entre forças regulares israelenses contra civis. Além disso, demonstra que Israel possui maior capacidade de proteger seu território contra os ataques palestinos que o oposto. Não só a violência política está mais presente na vida da população palestina, como também o maior número de vítimas fatais, o que torna essa população menos favorável a negociação e demonstra maior intransigência das partes na busca por solução para o conflito. Por fim, também é possível perceber pela análise do gráfico que, após o discurso de Donald Trump, no dia 06 de dezembro de 2017, houve uma escalada no número de vítimas fatais na região, o que confirma o papel interveniente do discurso na dinâmica do conflito. O pico de vítimas após o discurso foi em maio de 2018, quando ocorreram 184 óbitos ( $20 \%$ do total no período analisado), todos em território palestino, desses, 140 (76\%) ocorreram em 14 de maio, data da inauguração oficial da Embaixada dos Estados Unidos em Jerusalém. (White House 2018).

Contudo, vale ressaltar que os dados apresentados até aqui não incluem atos de violência cotidiana. Na díade Israel-Palestina, essa violência se manifesta 
majoritariamente de maneira unidirecional, envolvendo atos de violência política propagados por Israel, relacionados ao uso desproporcional da força, estabelecimento de assentamentos que levam ao aumento do número de deslocados palestinos, corriqueiras prisões arbitrárias, controle de fluxos de pessoas na Faixa de Gaza e na Cisjordânia, além do estabelecimento de leis discriminatórias por parte de Israel. (Human Rights Watch 2018, 2019).

Tanto em 2017 quanto em 2018, a Human Rights Watch $(2018,2019)$ denunciou o uso excessivo da força empregada por Israel para combater movimentos não violentos, o que gerou a morte e injúria de diversos palestinos que protestavam por seus direitos, muitos organizados de maneira não-violenta. Um exemplo desse uso desproporcional da força foi evidenciado em protestos que ocorreram em novembro de 2018 na fronteira entre Israel e Faixa de Gaza, quando forças israelenses receberam ordem de seus superiores para utilizar força letal contra todos os que, de alguma forma, causassem danos às cercas que separavam os dois territórios. Tal ato configura uma inobservância do Direito Internacional dos Direitos Humanos, haja vista que há uma proibição do uso de força letal a não ser em casos de ameaça física iminente. Em meio a tais protestos, diversas prisões arbitrárias também foram registradas, ocasião em que Israel alegou a necessidade de submeter palestinos, inclusive algumas crianças, à corte militar do país, cujo índice de condenação se aproxima dos 100\% dos casos julgados (Human Rights Watch 2018, 2019, International Crisis Group 2019).

Também é importante ressaltar as humilhações cotidianas e violações de direitos dos palestinos em regiões dos assentamentos israelenses. Durante o período analisado, diversos conjuntos habitacionais em territórios na Cisjordânia e na Faixa de Gaza foram autorizados por Israel, a despeito da resolução do Conselho de Segurança das Nações Unidas (CSNU), de 2016, que aponta para a ilegalidade dessa prática. É válido mencionar que os assentamentos, para além de serem ilegais do ponto de vista do direito internacional, são construídos, em grande parte dos casos, após a demolição de construções palestinas, sob o argumento de que estas foram feitas sem aprovação. Essa política de assentamentos e de demolição de vilarejos contribui para o número de deslocados palestinos forçados: 588 deslocados em 2017 e 407 em 2018. Estima-se que, em 2018, cerca de 18 mil pessoas se encontravam na condição de deslocados internos (Human Rights Watch 2018, 2019).

Outro tipo corriqueiro de violência cotidiana diz respeito ao intenso controle dos fluxos de bens e pessoas em território palestino. Esse é cercado por barreiras e 
cercas, construídas por Israel sob a prerrogativa da segurança nacional, existindo diversos checkpoints que controlam o trânsito da população palestina que se desloca para Israel e, também, em seu próprio território. Esse controle de mobilidade possui consequências humanitárias, como, por exemplo, a dependência de uma autorização para que a população palestina consiga ser atendida em hospitais em Israel. Nesse quesito, inclusive, observa-se redução, de 2017 para 2018, do número de autorizações concedidas para este fim. Além disso, Israel também controla as cargas direcionadas aos territórios palestinos e, sobretudo em 2018, reduziu o envio de materiais de construção, energia e produtos voltados para a ajuda humanitária. Tal medida impactou diretamente a vida cotidiana dos palestinos, sobretudo aqueles localizados nas cidades na Faixa de Gaza, já que aproximadamente 80\% da população palestina na região depende de bens humanitários básicos para sobreviver (Human Rights Watch 2018, 2019). Nesse sentido, evidencia-se que, apesar do número bruto de eventos de violência política propagados por atores palestinos e israelenses ser equilibrado em alguns casos, os palestinos estão muito mais expostos à violência cotidiana empregada por Israel, o que definitivamente contribui para uma vitimização dessa parte no conflito.

Outro componente da análise proposta é a necessidade de avaliar o andamento de negociações para a paz no período analisado, haja vista que a falha nas negociações também é uma das variáveis que contribuem para a intratabilidade dos conflitos. Dados coletados nos relatórios de acompanhamento do International Crisis Group (2019) evidenciam que o período de dezembro de 2016 a dezembro de 2017 marca a existência de negociações de acordos de cessar-fogo e negociações mais amplas para a paz. Em janeiro de 2017, setenta Estados se mobilizaram em uma conferência voltada para a paz no Oriente Médio, em que foi discutida, novamente, a possibilidade de criação de dois Estados independentes. Tal possibilidade de resolução do conflito foi inicialmente apoiada pela Autoridade Nacional Palestina (ANP), demonstrando disposição da representação palestina em negociar. Posteriormente, em maio de 2017, o governo israelense divulgou que iria realizar concessões econômicas para que a Palestina fosse capaz de combater a crise energética que cercava a Cisjordânia no período. Além disso, Israel anunciou no mesmo período que incentivo seria dado para a criação de duas zonas industriais na região, além de maior flexibilização na concessão de autorizações para construções palestinas no território da Cisjordânia. Outro avanço muito relevante no período se deu em agosto de 2017, quando Israel e a ANP decidiram retomar a coordenação política na agenda da segurança, após um 
período de instabilidade marcado por atos de violência que ocorreram no Monte do Templo, na cidade de Jerusalém (International Crisis Group 2019).

Seguindo essa ideia de retomada das negociações para a paz, em setembro de 2017 o Primeiro-Ministro israelense, Benjamin Netanyahu, encontrou-se com o presidente egípcio, Abdel-Fattah el-Sissi. Nesse contexto, el-Sissi se colocou disponível para mediar o conflito e auxiliar em conversações para a paz entre as partes. A postura mediadora do Egito se fez presente também em negociações que buscavam a reconciliação das facções palestinas Hamas e Fatah, representada pelo presidente da ANP, Mahmoud Abbas. As partes assinaram, em outubro de 2017, um acordo que visava flexibilizar barreiras econômicas impostas pela ANP à Faixa de Gaza e, em troca, o Hamas reconheceria a ANP como órgão responsável pelo controle civil na Faixa de Gaza e na Cisjordânia. Contudo, a implementação das cláusulas do acordo foi interrompida após a intensificação da violência com a declaração de Trump acerca do status de Jerusalém (International Crisis Group 2019).

Outro exemplo de retrocesso nas negociações foram as constantes violações dos acordos de cessar-fogo entre o governo de Israel e as forças do Hamas. Além disso, em virtude do posicionamento dos EUA a respeito de Jerusalém, a OLP se posicionou firmemente contra a alteração do status de Jerusalém e se negou a participar de qualquer tipo de negociação que envolvesse autoridades estadunidenses, alegando a parcialidade dos EUA no que tange a questões centrais do conflito. Em decorrência disso, a OLP mobilizou um discurso que buscou o esvaziamento dos Acordos de Oslo, assinados em 1993 e que deram fim à Primeira Intifada (1988-1993), afirmando que esses, por terem sido mediados pelos EUA, são nulos e vazios (International Crisis Group 2019). Desse modo, além do retrocesso em negociações em andamento, observa-se que, no período analisado, a legitimidade de acordos de paz anteriores também foi colocada em xeque em virtude da decisão estadunidense de reconhecer Jerusalém como a capital de Israel.

\section{Conclusões}

Observa-se, após o pronunciamento dos EUA sobre o status de Jerusalém, um aumento quantitativo dos eventos de violência política e do número de vítimas fatais, algo que leva imediatamente ao prolongamento do conflito. Conforme argumentado anteriormente, a intensificação da violência também promove maior 
antagonismo entre as partes, expresso também na interrupção de negociações de paz em andamento. A partir da análise dos dados, é possível inferir que o lado palestino pode estar mais propenso a tal antagonismo, tendo em vista que a maioria esmagadora dos eventos ocorre em seu território. Os dados sobre a violência cotidiana também evidenciam que palestinos são diariamente constrangidos pelas políticas de Israel voltadas para o controle do território, políticas de assentamento, prisões arbitrárias e uso desproporcional da violência contra civis palestinos, algo cotidiano devido à superioridade bélica do Estado de Israel. Pelo lado palestino, por sua vez, a violência política disseminada é difusa e a repressão do Estado de Israel torna mais fácil a identificação do inimigo (Estado de Israel), algo que pode conduzir os palestinos à disseminação de um discurso em que se atribuem o papel de vítimas das hostilidades.

Nesse sentido, as evidências aqui mobilizadas permitem avaliar positivamente a hipótese traçada, sobre o aumento do número de eventos violentos e o retrocesso nas negociações de paz após a declaração do presidente estadunidense sobre Jerusalém. A medida autorizada por Trump, de transferir a embaixada estadunidense para Jerusalém, manobra que tinha o objetivo simbólico de reconhecer o direito israelense sobre a terra santa, agiu como uma variável interveniente para a intratabilidade do conflito Israel-Palestina, na medida em que foi um gatilho para a intensificação da violência e promoveu uma estagnação nas negociações entre o Hamas e o Fatah, inviabilizando também a cooperação na agenda de segurança entre a ANP e Israel, além de promover o repúdio por parte da OLP em relação aos Acordos de Oslo, mediados pelos EUA na década de 1990.

De maneira geral, acredita-se que o presente artigo foi capaz de contribuir para a discussão acerca da intervenção de terceiros atores que adotam medidas parciais na dinâmica dos conflitos armados. Outras pesquisas nessa direção podem auxiliar o aprofundamento desta compreensão, seja pela observação, em outros conflitos armados, de uma possível relação entre a intensificação da dinâmica violenta de um conflito e a interferência de terceiros parciais em recursos em disputa; seja pelo desenvolvimento de estudos que avaliem, ainda que de forma casuística, se historicamente os picos de violência no conflito Israel-Palestina estão associados ao envolvimento estadunidense nas questões centrais da incompatibilidade entre as partes. De toda maneira, fica claro que em conflitos intratáveis a interveniência de terceiros atores, mesmo que pontual, pode ter desdobramentos muito significativos para a intensificação e prolongamento do conflito e, logo, para a manutenção da intratabilidade. 


\section{Referências}

ACLED. 2018. ACLED Definitions of Political Violence and Protest. ACLED. Disponível em: < https://www.acleddata.com/wp-content/uploads/2017/12/ACLED-Definitionsof-Political-Violence-and-Protest_FINAL.pdf > . Acesso em: 20 jun. 2018.

ACLED. 2019. Data. ACLED. Disponível em: < https://www.acleddata.com/data/ > . Acesso em 26 mar. 2019.

Aggestam, Karin. 1999. Reframing and Resolving Conflict: Israeli-Palestinian Negotiations 1988-1998. 1999. 286f. Tese (Doutorado) — Lund Political Studies, Lund University, Lund. Disponível em: < http://portal.research.lu.se/portal/files/4494879/4770171. pdf > . Acesso em: 29 maio 2018.

Avalos, Hector. 2005. Fighting Words: The origins of religious violence. New York: Prometheus.

Catherwood, Christopher. 2006. A Brief History of the Middle East: From Abraham to Arafat. New York: Carroll \& Graf.

Cherkaoui, Mohammed. 2017. Trump's Death Kiss on the Middle East Peace Process. Al Jazeera Centre for Studies, [S.1.], 11 dez. 2017. Disponível em: < http://studies.aljazeera. net/mritems/Documents/2017/12/12/ec6a13bb803d438a90bdf9faa47013c2_100. pdf > . Acesso em: 16 jun. 2018.

Crocker, Chester; Hampson, Fen; Aall, Pamela. 2004. Taming Intractable Conflicts: Mediation in the Hardest Cases. Washington D.C: USIP Press.

EUA. 1995. Jerusalem Embassy Act of 1995, Public Law 104-45. Washington D.C., 8 nov. 1995. Disponível em: < https://www.congress.gov/104/plaws/publ45/PLAW104publ45.pdf > . Acesso em: 20 maio 2018.

Galtung, Johan. 1969. Violence, Peace and Peace Reseach. Journal of Peace Research 6, no. 3:167-191. doi: 10.1177/002234336900600301

Gelvin, James L. 2011. The Modern Middle East: A history. $3^{\text {a }}$ ed. New York: Oxford Press. Harms, Gregory; Ferry, Todd M. 2017. The Palestine-Israel Conflict: A Basic Introduction. $4^{\mathrm{a}}$ ed. London: Pluto Press.

Human Rights Watch. 2018. Israel and Palestine - Events of 2017. Human Rights Watch, [S.1], World Report. Disponível em: < https://www.hrw.org/world-report/2018/ country-chapters/israel/palestine > . Acesso em: 16 out. 2019.

Human Rights Watch. 2019. Israel and Palestine - Events of 2018. Human Rights Watch, [S.1], World Report. Disponível em: < https://www.hrw.org/world-report/2019/ country-chapters/israel/palestine > . Acesso em: 16 out. 2019.

International Crisis Group. 2019. Crisis Watch Israel-Palestine. International Crisis Group, [S.1], Crisis Watch. Disponível em: < https://www.crisisgroup.org/crisiswatch > . Acesso em: 23 out. 2019. 
Kriesberg, Louis. 1993. Intractable conflicts. Peace Review: A Journal of Social Justice 5, no. 4: 417-421. doi: 10.1080/10402659308425753

Kriesberg, Louis. 2003. Nature of Intractability. Beyond Intractability, [S.1]. Disponível em: < http://www.beyondintractability.org > . Acesso em: 20 maio 2018.

Massoulié, François. 1996. Os Conflitos do Oriente Médio: Século XX. 2. ed. São Paulo: Ática.

Mearsheimer, John; Walt, Stephen. O lobby de Israel. Novos Estudos 76: 43-73. Disponível em: < http://www.scielo.br/pdf/nec/n76/03.pdf> . Acesso em:20 jul. 2018. doi: 10.1590/S0101-33002006000300003

Morris, Banny. 2008. "Revisiting the Palestinian exodus of 1948”. In Rogan, Eugene L.; Shlain, Avi (Eds.). The War for Palestine: Rewriting the History of 1948, 37-59. $2^{a}$ ed. New York: Cambridge Press.

ONU. 1947. Resolution adopted on the report of the ad hoc committee on the Palestinian question, A/RES/181(II) A. ONU, 29 nov. 1947. Disponível em: < http://www.un.org/ en/ga/search/view_doc.asp?symbol=A/RES/181(II) > . Acesso em: 20 maio 2018.

Oren, Neta et al. 2004. "Conflict, Identity and Ethos: The Israeli-Palestinian Case”. In Lee, Yue-Ting et al. (Eds.). The Psychology of Ethnic and Cultural Conflict, 133-154. Westport: Praeger.

Quigley, John. 1994. The Legal Status of Jerusalem under International Law. The Turkish Year Book 24: 11-23.

Wallensteen, Peter. 2007. Understanding Conflict Resolution: War, Peace and the Global System. London: Sage Publications.

Weingrod, Alex. 2005. "Israel: Ethnic Conflict and Political Exchange”. In: Coackley, John. (Ed.). The territorial management of ethnic conflict, 118-142. $2^{\mathrm{a}}$ ed. [S.1.]: Taylor \& Francis e-Library.

White House. 2017. Statement by President Trump on Jerusalem. Disponível em: < https:// www.whitehouse.gov/briefings-statements/statement-president-trump-jerusalem/ > . Acesso em: 25 jun. 2018.

White House. 2018. President Donald J. Trump keeps his promise to open U.S. Embassy in Jerusalem, Israel. Disponível em: < https://www.whitehouse.gov/briefingsstatements/president-donald-j-trump-keeps-promise-open-u-s-embassy-jerusalemisrael/ > . Acesso em 27 jul. 2018. 